\title{
.RESPON PENAMBAHAN TEPUNG DAUN KELOR DALAM RANSUM MENGANDUNG SEKAM PADI DISUPLEMENTASI STARPIG TERHADAP PRODUKSI DAN KUALITAS FISIK TELUR ITIK BALI
}

\author{
TRISNADEWI, A. A. A. S., I. B. G. PARTAMA, DAN T. G. B. YADNYA \\ Fakultas Peternakan Universitas Udayana \\ Jl. PB. Sudirman Denpasar, Bali \\ e-mail: aaas_trisnadewi@unud.ac.id
}

\begin{abstract}
ABSTRAK
Penelitian bertujuan untuk mengetahui respon pemberian tepung daun kelor (Moringa oleifera) dalam ransum mengandung sekam padi disuplementasi Starpig terhadap produksi dan kualitas telur itik bali. Penelitian menggunakan rancangan acak lengkap (RAL) dengan empat perlakuan yaitu ransum kontrol (tanpa sekam padi, tepung daun kelor, dan starpig = A), ransum mengandung 10\% sekam padi (B), ransum mengandung 10\% sekam padi dan tepung daun kelor (C), ransum mengandung 10\% sekam padi, tepung daun kelor dan Starpig (D). Setiap perlakuan dengan empat ulangan dan setiap ulangan berisi tiga ekor itik bali betina. Variabel yang diamati adalah produksi dan kualitas telur terdiri atas konsumsi ransum, jumlah telur, hen day production, bobot telur rerata, bobot telur total, dan feed conversion rasio. Hasil penelitian menunjukkan bahwa perlakuan (B) nyata menurunkan jumlah telur dan produksi telur harian daripada pemberian perlakuan A, tetapi pemberian perlakuan C dan D nyata meningkatkan jumlah telur, produksi telur harian, bobot telur rerata, dan bobot telur total dibandingkan dengan pemberian perlakuan kontrol (A). Pemberian perlakuan B dapat meningkatkan konsumsi ransum tetapi pemberian perlakuan $\mathrm{C}$ dan $\mathrm{D}$ tidak berpengaruh terhadap konsumsi ransum. Pemberian perlakuan D nyata menurunkan FCR telur dibandingkan dengan pemberin perlakuan A. Dari hasil penelitian dapat disimpulkan bahwa pemberian tepung tepung daun kelor (Moringa oleifera) dalam ransum sekam padi disuplementasi dengan Starpig dapat memperbaiki produksi dan kualitas fisik telur itik bali.
\end{abstract}

Kata kunci: tepung daun kelor, itik bali, kualitas fisik telur, produksi, sekam padi

\section{RESPONSE OF ADDITIONAL Moringa oleifera LEAF MEAL IN RATION CONTAINS RICE HULL SUPLEMENTED WITH STARPIG TO PRODUCTION AND EGG PHYSICAL QUALITY OF BALI DUCK}

\begin{abstract}
The study aimed to determine the response of Moring a oleifera leaf meal in ration contains rice hull supplemented with Starpig to production and quality of bali duck eggs. The study used a completely randomized design with four treatments as of control ration (without rice hull, Moringa leaf meal, and starpig = A), ration containing 10\% rice hull (B), ration containing 10\% rice hull and Moringa leaf meal (C), ration contains 10\% rice hull, Moringa leaf meal and Starpig (D). Each treatment with four replications and each replication contains three female bali ducks. The variables observed were production and quality of egg consisting of feed consumption, number of egg, hen day production, egg average weight, egg total weight, and feed conversion ratio (FCR), and egg quality consisting of water, protein, fat and total cholesterol. The results showed that the addional of Moringa oleifera leaf meal in rice hull ration (B) significantly decreased the number of eggs and daily egg production than the treatment $\mathrm{A}$, but treatment $\mathrm{C}$ and $\mathrm{D}$ significantly increased the number of eggs, daily egg production, egg average weight, egg total weight compared with treatment $\mathrm{A}$. Additional of treatment $\mathrm{B}$ could increase the consumption of ration but treatment $\mathrm{C}$ and D not affect ration consumption. Treatment D significantly decreased FCR compared with treatment A. It can be concluded that the additional of Moringa oleifera leaf meal in ration contains rice hull supplemented with Starpig could improve production performance and physical quality of bali duck eggs.
\end{abstract}

Key words: Moringa oleifera leaf meal, bali duck, physical quality of eggs, egg production, rice hull 


\section{PENDAHULUAN}

Upaya untuk meningkatkan produktivitas ternak memerlukan ketersediaan bahan pakan yang cukup banyak berkisar $60-70 \%$ biaya yang digunakan dalam suatu peternakan (Nitis, 1980) sehingga diperlukan bahan ransum yang berasal dari bahan ransum alterntif antara lain sekam padi. Dalam penggilingan gabah menjadi beras dihasilkan beras berkisar $50-63 \%$, dedak padi berkisar 8 - $12 \%$, dan sekam padi berkisar 20 - 30\% (Suharno, 1979). Kandungan nutrisi daripada sekam padi adalah 12,5\% air, 3,1\% protein kasar, 29,2\% Bahan Ekstrak Tiada Nitrogen (BETN), serat kasar 35\%, 2,7\% lemak, dan 17,5\% abu dengan kecernaan yang rendah (Lubis, 1992), dan akan berpengaruh terhadap efisiensi penggunaan ransum, maka perlu difermentasi, agar nilai nutrisinya bisa diperbaiki (Widyanto, 1995). Salah satu inokulan yang baik digunakan mencerna bahan ransum yang tinggi serat kasar adalah starbio (Multifarm, 1993). Disamping itu diperlukan multivitamin mineral dan methionin yang terdapat dalam bentuk pignox (Medion, 1993), dan apabila dikombinasikan antara starbio dan pignox disebut dengan starpig. Starbio merupakan probiotik yang mengandung enzim-enzim selulase, lipase, dan proteolitik yang membabtu proses pencernaan, amilum menjadi glukosa, lemak oleh enzim lipasemenjdi asam lemak dan trigliserol, protein oleh enzim protease menjadi asam-asam amino. Pignox menyediakan bahan pelengkap ransum yang diperlukan oleh ternak berupa mineral $\mathrm{Zn}, \mathrm{Mn}$, dan selenium merupakan mineral yang sangat diperlukan untuk oleh aktivitas enzim Superoksida Dismutase (SOD) untuk menetralkan radikal bebas (Kumalaningsih, 2008).

Hasil penelitian Roni et al. (2006) mendapatkan bahwa pemberian ransum sekam padi dimoniasi urea dan disuplementasi Starbio tidak berpengaruh terhadap bobot potong, bobot karkas, namun dapat meningkatkan persentase karkas, pesentase daging dan dapat menurunkan persentase lemak karkas. Susila et al. (2015) mencoba pemberian sekam padi dengan taraf $5 \%, 10 \%$ dan $15 \%$ baik yang terfermentasi atau tanpa fermentasi disuplementasi daun ubi jalar ungu (Ipomoea batatas L.) diperoleh pemberian 10\% sekam padi terfermentasi dan disuplementasi daun ubi jalar memperoleh hasil yang terbaik terhadap efisiensi penggunaan ransum dan dapat memperbaiki profil lipida daging itik bali. Selanjutnya Yadnya et al. (2017) melaporkan bahwa pemberian ransum sekam padi mengandung daun noni (Morinda citrifolia L) disuplementasi multienzim vitamin dan mineral dapat memperbaiki kapasitas antioksidan ransum, nutrisi telur dan profil lipida telur itik bali.

Berdasarkan uraian di atas maka dilakukan penelitian tentang respon penambahan tepung daun kelor (Moringa oleifera) dalam ransum sekam padi yang disuplementasi Starpig terhadap penampilan produksi dan kualitas fisik telur pada itik bali.

\section{MATERI DAN METODE}

\section{Tempat dan Lama Penelitian.}

Penelitian dilaksanakan di Desa Guwang selama 10 minggu dan analisis fisik telur dilaksanakan di Laboratorium Teknologi Hasil Ternak Fakultas Peternakan, Universitas Udayana Denpasar.

\section{Itik}

Itik yang digunakan dalam penelitian adalah itik bali umur 22 minggu dengan kisaran bobot badan awal berkisar 1166,06 $\pm 1,78 \mathrm{~g}$.

\section{Kandang dan perlengkapannya}

Penelitian menggunakan kandang sistem battery colony berlantai dua sebanyak 16 petak dan setiap petak kandang berukuran panjang $70 \mathrm{~cm}$, lebar $60 \mathrm{~cm}$, dan tinggi $70 \mathrm{~cm}$. Kandang dilengkapi dengan tempat pakan dan tempat minum yang terbuat dari bilah bilah bambu yang letaknya di luar kandang. Kandang dilengkapi dengan tempat penampung kotoran serta penampung sisa makanan, dan lampu untuk penerangan pada malam hari.

\section{Ransum}

Ransum terdiri dari jagung kuning, kacang kedelai, bungkil kelapa, dedak padi, mineral B12, garam dapur $(\mathrm{NaCl})$, starbio sebagai sumber multienzim, dan pignox sebagai sumber vitamin, mineral, antioksidan dan methionin serta minyak kelapa. Komposisi ransum disajikan pada Tabel 1.

\section{Metoda}

Penelitian menggunakan rancangan acak lengkap (RAL) dengan empat perlakuan yaitu ransum tanpa sekam padi, tepung daun kelor, dan starpig (A), ransum mengandung $10 \%$ sekam padi (B), ransum mengandung $10 \%$ sekam padi dan $1 \%$ tepung daun kelor (C), ransum mengandung $10 \%$ sekam padi, $1 \%$ tepung daun kelor dan $1 \%$ starpig (D).

Setiap perlakuan dengan empat ulangan dan setiap ulangan berisi tiga ekor itik bali betina umur 22 minggu dengan bobot badan yang homogen, sehingga terdapat 48 ekor itik. Komposisi bahan ransum disajikan pada Tabel 1, sedangkan komposisi kimia ransum disajikan pada Tabel 2. 
Tabel 1. Komposisi bahan penyusun ransum itik bali umur $22-34$ minggu

\begin{tabular}{lcccc}
\hline \multirow{2}{*}{$\begin{array}{c}\text { Komposisi ranasum } \\
\text { (\%) }\end{array}$} & $\mathrm{4}$ & $\mathrm{B}$ & $\mathrm{C}$ & $\mathrm{D}$ \\
\cline { 2 - 5 } Jagung kuning & 55,36 & 49,98 & 49,98 & 49,98 \\
Kacang kedelai & 9,37 & 12,45 & 12,45 & 12,45 \\
Bungkil kelapa & 11,31 & 9,82 & 9,82 & 9,82 \\
Tepung ikan & 10,13 & 8,10 & 8,10 & 8,18 \\
Dedak padi & 13,18 & 7,00 & 7,00 & 7,00 \\
Sekam padi & - & 10,00 & 10,00 & 10.00 \\
Starpig & - & - & - & 1,00 \\
Mineral B12 & 0,50 & 0,50 & 0,50 & 0,50 \\
NaCl & 0,15 & 0,15 & 0,15 & 0,15 \\
Tepung daun kelor & - & - & 1,00 & 1,00 \\
Minyak kelapa & - & 2 & 2 & 2 \\
Total & 100 & 100 & 100 & 100 \\
\hline
\end{tabular}

Keterangan

A: ransum tanpa mengandung sekam padi, tanpa tepung daun kelor dan tanpa starpig, B: ransum mengandung $10 \%$ sekam padi, C: ransum mengandung $10 \%$ sekam padi dan $1 \%$ tepung daun kelor, D: ransum mengandung $10 \%$ sekam padi, $1 \%$ tepung daun kelor dan $1 \%$ starpig

\section{Variabel yang diamati}

Variabel yang diamati adalah penampilan produksi dan kualitas fisik telur terdiri atas konsumsi ransum, jumlah telur, hen day production, bobot telur rerata, bobot telur total, dan feed conversion rasio (FCR), serta kualitas fisik telur terdiri atas warna kuning telur, indeks telur, Hough Unit (HU), komposisi fisik telur, tebal kuli telur, dan total kolesterol telur.

\section{Analisis Data}

Data yang diperoleh dianalisis dengan sidik ragam dan apabila terdapat perbedaan yang nyata diantara perlakuan dilanjutkan dengan uji Duncan (Steel dan Torrie, 1989)

\section{HASIL DAN PEMBAHASAN}

\section{Jumlah Telur}

Jumlah telur yang dihasilkan pada itik yang mendapatkan perlakuan A adalah 43,0 butir/ekor selama penelitian. (Tabel 2). Pemberian perlakuan
B dapat menurunkan jumkah telur yang dihasilkan sejumlah $8,13 \% \quad(\mathrm{P}<0.05)$, sedangkan pemberian perlakuan $\mathrm{C}$, dan $\mathrm{D}$ dapat meningkatkan jumlah telur yang dihasilkan masing - masing adalah $8,139 \%$ dan $17,44 \% \quad(\mathrm{P}<0,05)$ dibandingkan dengan pemberian perlakuan A. Pemberian $10 \%$ sekam padi tanpa fermentasi dapat menurunkan kecernaan ransum, sehingga zat nutrisi yang dapat dimanfaatkan akan berkurang sehingga berpengaruh jumlah telur yang dihasilkan. Hasil penelitian ini sesuai dengan yang dilakukan oleh Yadnya dan Wirawan (2016) namun pemberian tepung daun kelor atau tepung daun kelor dan Starpig dapat meningkatkan jumlah telur. Adanya tepung daun kelor dapat menurunkan aktivitas bakteri yang patogen. Yadnya (2013) melaporkan pemberian ubi jalar ungu sebagai bahan antioksidan dapat menurunkan bakteri Escherichiac coli sehingga bakteri yang non patogen dapat berkembang dengan baik yang dapat membantu meningkatkan kecernaan ransum sehingga jumlah telur yang diperoleh pada pemberian perlakuan C atau D meningkat. Yadnya dan Wirawan (2016) melaporkan pemberian ransum sekam padi yang difermentasi larutan EM-4 yang disuplementasi daun noni (Morinda citrifolia) dapat meningkatkan jumlah telur secara nyata dibandingkan dengan pemberiann kontrol atau pemberian sekam padi tanpa fermentasi.

\section{Hen Day Production (Produksi telur harian)}

Produksi telur harian pada itik yang mendapatkan perlakuan kontrol adalah 60,56\% (Tabel 3). Pemberian perlakuan B dapat menekan produksi telur sebesar 8,22\% $(\mathrm{P}<0,05)$ lebih rendah darpada perlakuan $\mathrm{A}$, sedangkan pemberian perlakuan $\mathrm{C}$ dan $\mathrm{D}$ dapat meningkatkan produksi telur masing-masing 7,54\% dan 17,43\% $(\mathrm{P}<0,05)$ dibandingkan dengan pemberian perlakuan kontrol (A). Yadnya dan Trisnadewi (2009) melaporkan pemberian $10 \%$ sagu cincang yang disuplementasi dengan Starpig dapat meningkatkan produksi telur secara nyata dibandingkan dengan pemberian ransum kontrol. Hasil penelitian ini sesuai dengan hasil penelitian yang dilakukan oleh Satria

Tabel 2. Respon penambahan tepung daun kelor (Moringa oleifera) dalam ransum mengandung sekam padi yang disuplementasi starpig terhadap performans produksi itik bali

\begin{tabular}{|c|c|c|c|c|c|}
\hline \multirow{2}{*}{ Variabel } & \multicolumn{4}{|c|}{ Perlakuan ${ }^{1)}$} & \multirow{2}{*}{ SEM $^{3)}$} \\
\hline & A & B & C & $\mathrm{D}$ & \\
\hline Jumlah telur (butir/ekor) & $43,00 c$ & $39,50 d$ & $46,50 b$ & $50,50 a$ & 0,478 \\
\hline Produksi telur harian (\%) & $60,56 c$ & $55,58 d$ & $65,13 b$ & $71,12 a$ & 0,670 \\
\hline Bobot telur rerata (g/butir) & $69,03 a$ & $67,71 a$ & $69,32 a$ & $69,64 a$ & 0,863 \\
\hline Bobot telur total (g/ekor) & $2948,00 b c$ & $2724,50 c$ & $3103,75 b$ & $3454,75 a$ & 76,16 \\
\hline Feed conversion rasio (FCR) & $3,705 b$ & $4,255 a$ & $3,562 b c$ & $3,41 c$ & 0,086 \\
\hline
\end{tabular}

Keterangan
1) A: ransum tanpa mengandung sekam padi, tanpa tepung daun kelor dan tanpa starpig, B: ransum mengandung $10 \%$ sekam padi, C: ransum mengandung $10 \%$ sekam padi dan $1 \%$ tepung daun kelor, D: ransum mengandung $10 \%$ sekam padi, $1 \%$ tepung daun kelor dan $1 \%$ starpig

2) Nilai dengan huruf yang berbeda pada baris yang sama berarti berbeda nyata $(P<0,05)$

3) SEM: Standard Error of the Treatment Means 
Tabel 3. Respon penambahan tepung daun kelor (Moringa oleifera) dalam ransum sekam padi disuplementasi starpig terhadap kualitas fisik telur itik bali

\begin{tabular}{|c|c|c|c|c|c|}
\hline \multirow{2}{*}{ Variabel } & \multicolumn{4}{|c|}{ Perlakuan $^{1)}$} & \multirow{2}{*}{$\mathrm{SEM}^{3)}$} \\
\hline & A & B & C & D & \\
\hline Warna kuning telur & $8,625 b c^{2)}$ & $7,675 c$ & $10,125 a b$ & $11,450 a$ & 0,652 \\
\hline Indeks telur (\%) & 67,45 & 67,43 & 67,62 & 70,17 & 2,301 \\
\hline Hough Unit & $83,30 a b$ & $79,175 b$ & $90,925 a b$ & $100,60 a$ & 0,745 \\
\hline Tebal kulit telur (mm) & 0,5625 & 0,5825 & 0,5875 & 0,5725 & 7,416 \\
\hline \multicolumn{6}{|l|}{ Komposisi fisik telur (\%) } \\
\hline Kulit & 10,65 & 11,63 & 11,93 & 12,07 & 0,929 \\
\hline Putih & 48,58 & 45,65 & 45,44 & 45,38 & 1,266 \\
\hline Kuning & 40,770 & 42,72 & 42,63 & 42.55 & 1,086 \\
\hline
\end{tabular}

Keterangan $1 \%$ tepung daun kelor, D: ransum mengandung $10 \%$ sekam padi, $1 \%$ tepung daun kelor dan $1 \%$ starpig

2) Nilai dengan huruf yang berbeda pada baris yang sama berarti berbeda nyata $(P<0,05)$

3) SEM: Standard Error of the Treatment Means

(2017) bahwa pemberian tepung daun kelor sampai pada $2 \%$ tepung daun kelor (Moringa oleifera) dapt meningkatkan produksi telur ayam petelur, dengan adanya tepung daun kelor dapat membunuh bakteri Echirichia coli, sehingga jumlah bakteri non patogen semakin banyak dapat membantu dalam proses pencernaan, sehingga zat nutrisi yang terserap lebih banyak dan akan berpengaruh terhadap produksi telur yang lebih tinggi.

\section{Bobot Telur Rerata}

Pemberian ransum A menghasilkan bobot telur rerata adalah adalah 67,03 g/butir (Tabel 3). Pemberian perlakuan $\mathrm{B}$ dapat menurunkan bobot telur rerata secara tidak nyata $(\mathrm{P}>0,05)$, namun pemberian perlakuan $\mathrm{C}$ dan $\mathrm{D}$ dapat meningkatkan produksi telur sebesar $3,02 \%$ dan $4,81 \%$ berbeda nyata $(\mathrm{P}<0,05)$ dibandingkan dengan pemberian perlakuan A.Hasil penelitian ini sesuai dengan yang dilakukan oleh Yadnya dan Wirawan (2016) melaporkan penambahan daun noni (Morinda citrifolia) dalam ransum sekam padi yang disuplementasi Starpig dapat meningkatkan produksi telur secara nyata $(\mathrm{P}<0,05)$ dibandingkan dengan pemberian ransum kontrol (A). Sependapat dengan Satria (2017) melaporkan bahwa penambahan 2\% tepung daun kelor (Waringa oleifera) dalam ransum dapat meningkatkan produksi telur ayam petelur

\section{Bobot telur total}

Bobot telur total yang dihasilkan oleh itik A adalah 2948,00 g/ekor. Pemberian ransum B dapat menurunkan bobot telur total sebesar 7,58\% $(\mathrm{P}<0,05)$ Pemberian perlakuan Cdan D dapat meningkatkan bobot telur total masing-masing sebesar 5,28\% dan $17,18 \%$ $(\mathrm{P}<0,05)$ daripada pemberian perlakuan A. Penurunan bobot telur total pada itik yang mendapatkan perlakuan B disebabkan oleh jumlah telur dan bobot telur rerata yang dihasilkan lebih rendah daripada pemberian perlakuan A, C atau D. Hasil penelitian ini sesuai dengan diperoleh oleh Yadnya dan Trisnadewi (2009), Yadnya dan Wirawan (2016) dan Satria (2017). Pada prinsipnya dengan adanya fermentasi dan pemberian dedaunan yang mengandung zat antioksidan dapat meningkatkan bobot telur total secara nyata $(\mathrm{P}<0,05)$ dibandingkan pemberian ransum kontrol atau yang diberikan ransum sekam padi tanpa bantuan zat probiotik.

\section{Feed Conversion Rasio (FCR)}

FCR pada itik A adalah 3,705 (Tabel 5.1). Pemberian ransum dapat meningkatkan secara nyata sebesar $14,84 \%(\mathrm{P}<0,05)$ daripada pemberian perlakuan A. Pemberian perlakuan $\mathrm{C}$ dapat menurunkan FCR secara tidak nyata $(\mathrm{P}>0,05)$, sedangkan pemberian perlakuan $\mathrm{D}$ dapat menurunkan FCR sebesar 7,96\% $(\mathrm{P}<0,05)$ berbeda nyata daripada pemberian perlakuan A. Hasil penelitian ini sesuai dengan yang diperoleh Yadnya dan Trisnadewi (2009) bahwa pemberian ransum sekam padi yang disuplementasi Starpig dapat menurunkan FCR secara nyata $(\mathrm{P}<0,05)$. Satria (2017) melaporkan pemberian tepung daun kelor $2 \%$ daun menurunkan konversi ransum secara nyata $(\mathrm{P}<0,05)$.

\section{Warna Kuning Telur}

Warna kuning telur pada itik yang diberikan perlakuan A adalah 7,675 ( Tabel 5.2). Pemberian perlakaun $\mathrm{B}$ dapat meningkatkan warna kuning telur sebesar 11,01\%. (P>0,05) daripada perlakuan A. Pemberian perlakuan $\mathrm{C}$ dan $\mathrm{D}$ dapat meningkatkan warna kuning telur sebesar 31,92\% dan 49,18 berbeda nyata $(\mathrm{P}<0,05)$ daripada pemberian perlakuan $\mathrm{A}$.

Warna kuning telur sangat dipengaruhi oleh banyak - sedikit kandungan karotin sehingga vitamin A yang terdapat pada sekam tidak dapat dimanfaatkan secara maksimal, sehingga warna kuning telur agak pucat dan kurang kuning, berbeda dengan warna kuning telur pada yang mendapatkan perlakuan $\mathrm{C}$ dan $\mathrm{D}$, warna 
kuning telur lebih terang dengan kekentalan yang cukup tinggi, warna kuning disebabkan adanya komponen yang terdapat pada tepung daun kelor yang kaya akan antioksidan, vitamin A, B, C, D, E, K, asam folat dan biotin, serta mineral kalsium, besi, magnesium, kalium, selenium dan asam amino esensial yang lainnya (Nur Cholis dalam Satria, 2017).

\section{Indeks Telur}

Itik yang mendapatkan perlakuan A menghasilkan indeks telur sebesar 67,45 (Tabel 5.2). Pemberian perlakuan B menghasilkan indeks telur lebih rendah, namun belum berbeda nyata, sedangkan pemberian perlakuan $\mathrm{C}$ dan $\mathrm{D}$ ada kecenderungan indeks telur lebih tinggi, tetapi tidak berbeda nayata $(\mathrm{P}>0,05)$ dibandingkan dengan pemberian perlakuan A. Hasil penelitian ini sesuai dengan yang dilakukan oleh Yadnya dan Wirawan (2016) yang mendapatkan pemberian ransum sekam padi yang mengandung daun noni (Morinda citrifolia) menghasilkan bobot telur dan indeks telur yang lebih baik daripada pemberian ransum kontrol.

\section{Hough Unit (HU)}

Hought unit (HU) telur itik A adalah 83,30 (Tabel 5.2). Pemberian perlakuan $B$ dapat menurunkan HU, dan pemberian perlakuan $\mathrm{C}$ dan $\mathrm{D}$ dapat meningkatkan nilai $\mathrm{HU}$, namun tidak berbeda nyata $(\mathrm{P}>0,05)$. Besarnya nilai HU sangat tergantung pada bobot telur, semakin besar bobot telur dan persentase putih telur maka nilai HU akan lebih besar (Yadnya dan Trisnadewi, 2009).

\section{Tebal Kulit Telur}

Tebal kulit telur pada itik yang mendapatkan perlakuan A adalah o,5625 mm (Tabel 3). Pemberian perlakuan B , C dan D dapat meningkatkan tebal kulit telur, namun secara statistiktidak berbeda nyata $(\mathrm{P}>0,05)$. Tebal kulit telur sangat tergantung daripada bobot telur serta jenis ransum yang diberikan. Yadnya dan Wirawan (2016)mendapatkan pemberian ransum sekam padi yang mengandung daun noni disuplementasi multienzim mendapatkan peningkatkan kulit yang berbeda nyata, sedangkan pemberian ransum dengan sumber serat berbeda yang disuplementasi Starbio menghasilkan tebal kulit telur yang tidak berbeda $(\mathrm{P}>0,05)$ dibandingkan dengan pemberian ransum kontrol.

\section{Komposisi fisik telur}

Komposisi fisik telur yang terdiri atas putih, kuning dan kulit telur pada itik yang mendapatkan perlakuan A adalah 10,65\% kulit telur, 40,77\% kuning telur dan $48,58 \%$ putih telur. Pemberian perlakuan B, C dan $\mathrm{D}$, cenderung menghasilkan peningkatan kulit telur, penurunan putih dan peningkatan pada kuning telur, namun secara statistik tidak berbeda nyata $(\mathrm{P}>0,05)$ dibandingkan dengan pemberian perlakuan A. Hasil penelitian sesuai dengan pemberian ransum dengan sumber serat yang berbeda dan disuplementasi dengan starbio (Yadnya, 2003).

\section{SIMPULAN}

Dari hasil penelitian dan pembahasan dapat disimpulkan bahwa penambahan tepung daun kelor (Moringa oleifera) dalam ransum sekam padi disuplementasi Starpig dapat memperbaiki penampilan produksi telur ditandai dengan peningkatan pada jumlah telur, hen day production, bobot telur rerata, bobot telur total, bobot badan akhir serta dapat menurunkan FCR telur, dan memperbaiki kualitas fisik telur yang ditandai dengan peningkatan warna kuning telur dan Hough Unit telur, sedangkan tidak berpengaruh pada tebal kulit telur dan komposisi fisik telur.

\section{DAFTAR PUSTAKA}

Kumalaningsih,S. 2008. Antioksidan SOD (Superoksida dismutase) antioxidant. Centre.Com. http ://antioxidant Centre, Com (Januari 2008).

Lubis, D. A. 1992. Ilmu Makanan Ternak. PT. Pembanguan, Jakarta.

Roni, N. G. K., N. M. S. Sukmawati, N. L. P. Sriyni. 2006. Pengaruh Pemberian Ransum Mengandung Sekam Padi Diamoniasi disuplementasi dengan Zat Probiotik terhadap Bobot Badan, Perlemakan Tubuh, dan Karkas Ayam Broiler. Laporan Penelitian, Fakultas Peternakan, Universitas Udayana.

Steel, R. G. D and J. M. Torrie.1989. Priciples and Procedure of Statistic. Mc.Graw Hill Book Co Inc. New York, London.

Susila, T. G. O. dan T. G. Belawa Yadnya. 2016. Kajian Pemanfaatan Sekam Padi Terfermentasi Disuplementasi Daun Ubi Jalar (Ipomoea batatas L) terhadap Penampilan dan Produksi Telur Itik Bali pada Fase Peneluran Pertama. Laporan Penelitian Hibah Unggulan Program Studi. Tahun Anggaran 2016.

Satria, E. W. 2017. Respon Pemberian Tepung Daun Kelor (Moringa oleifera) dalam Pakan terhadap Penampilan Produksi dan Kualitas Telur Ayam Petelur. Tesis. Universitas Brawijaya.

Witariadi, N. M., N. G. K. Roni, D. P. M. A. Candrawati, dan A. A. A. S. Trisnadewi. 2012. Kualitas Karkas Itik Bali Umur 23 Minggu yang diberikan Ransum Ubi Jalar Ungu (Ipomoea batatas L) yang Terfermentasi. Laporan Penelitian. Fakultas Peternakan, Universitas Udayana.

Widyanto, E. Pangestu, Surahmanto, F. Wahyono, dan 
B. I. M. Tampubolon. 1994. Teknologi Pengolahan Pupuk Tebu untuk Meningkatkan Daya Gunanya sebagai Pakan Ruminan. Laporan Penelitian, Fapet, Undip, Semarang.

Yadnya, T. G. B. 2003. The response of starbio probiotic supplementation in diets different crude fibre content on the production and egg quality of bali ducks. Proceeding International Conference on Redesgning Sustainable Development on Food and Agricultural System for Developing Countries, September 17-18, 2003. Gadjah Mada University, Yogyakarta, Indonesia.

Susila, T. G. O., T. G. B.Yadnya, dan N. G. K. Roni. 2017. Kajian Pemanfaatan Sekam Padi Terfermentasi Disuplementasi Daun Ubi Jalar Ungu (Ipomoea batatas L) terhadap Penampilan, Karkas, dan Kualitas Daging Itik Bali. Laporan Penelitian Hibah Unggulan DIKTI.
Yadnya, T. G. B. 2009. Kajian Pemanfaatan Daun Ketela Pohon (Manihot sculenta Crantz) disuplementasi Starpig terhadap, penampilan, produksi dan kualitas telur iti bali. Makalah Seminar Internasional, AINI, Fakultas Peternakan, Universitas Jenderal Soedirman, Purwokerto.

Yadnya, T. G. B. dan A. A. A. S. Trisnadewi. 2011. The response of sago (Metroxylon sago Rottb) offered in the ration spplemented with probiotic on production and physical quality of duck's egg. Indon. J. Nutr. and Feed Sci. p. 1-5. ISSN 1410-2390.

Yadnya, T. G. B., N. M. S. Sukmawati., dan I W. Wirawan. 2013. Pemanfaatan daun ubi jalar ungu dalam ransum disuplementasi starpig terhadap kadar koleaterol serum darah dan karkas itik bali. Makalah Seminar Nasional, di Fakultas Agroindustri, Universitas Mercu Buana, Yogyakarta, 9 Oktober 2013. 